Volume 6 Issue 4, December 2019

Nationally Accredited Journal,

Decree No. B/4130/E5/E5.2.1/2019

\title{
Dispute over Double Certificate on the National Land Agency of Indramayu District
}

\author{
Titi Resmiyanti ${ }^{1}$, Akhmad Khisni ${ }^{2}$ and Achmad Sulchan ${ }^{3}$
}

Abstract. The purpose of this study was to: 1) Analyze the dispute resolution on dual certificates in the National Land Agency Indramayu district, 2) Barriers and Solutions Upon completion of Certificate Associate at the National Land Agency Indramayu district.

The approach used in this paper is empirical sociological juridical with the help of primary data or empirical data as the main data. Sociological research empirical law is a legal research methods that identify and conceptualize law as a social institution rill and functional in a real life system. The data collection was obtained by interview and literature. The data were analyzed qualitatively normative.

The research results are: 1). Settlement of disputes over double certificates in the National Land Agency Indramayu district that summons to the parties to the dispute to mediation. If mediation is not successful then the case was continued with the proceedings. The process of settlement is with the trial. Aspects that influence the judge determines the choice of action in the resolution of a dispute ie double certificate in terms of proof, because the facts and events as the principal case will be known judge from the evidence submitted by the parties to the dispute 2). Obstacles in solving the double certificate in Indramayu district that is party to the dispute does not come in mediation, data submitted on the land question is not clear, each party wants to win the case and the importance of their own interests. Solutions that can be done is the mediator to give some advice to the parties so that more can cooperate in following the legal process, so that the process can be completed justice and it takes a long time.

Keywords: Dispute; Double Certificate; BPN.

\section{Introduction}

Law of Agrarian guided by the principle that to get to the ideals mandated by Article 33, paragraph (3) of the Constitution of 1945 was unnecessary and out of place if the State (as the organizational power of the entire nation of Indonesia) to the owner in the civil sense of the earth, water and other natural resources, but the right is the state as such Ruler Agency understanding that must be understood by the managers of state power and the apparatus-officers and the community about the meaning of the state in the provisions of article 2, paragraph (1) Law Basic Agrarian law, which says that the earth, water and space, including the natural resources contained therein, at the highest levels controlled by the State. ${ }^{4}$ Each land rights acquired through rights application event shall be registered at the land office BPN (formerly the Agricultural Office) in each regency / municipality.

In order to ensure legal certainty in the field of land tenure and ownership lies the certainty factor and limit each plot can not be ignored. That is where the state has the

\footnotetext{
${ }^{1}$ Student Master of Notary Program, Unissula, Email: titi.resmiyanti84@gmail.com

${ }^{2}$ Lecturer, Faculty of Law, Sultan Agung Islamic University, Semarang

3 Lecturer, Faculty of Law, Sultan Agung Islamic University, Semarang

${ }^{4}$ Arie S. Hutagalung 2005, Perlindungan Pemilikan Tanah dari Sengketa Menurut Hukum Tanah Nasional,Tebaran Seputar Masalah Hukum Tanah, Lembaga Pemberdayaan Hukum Indonesia, p. 295.
} 
power regulate the lands that had been owned by a person or legal entity free lands which are not possessed person or legal entity will be directly controlled by the state. ${ }^{5}$ In the Basic Agrarian Law was never mentioned title deed, but as found in Article 19 paragraph (2) c was no mention of a "letter of proof of the right". In the letter the everyday sense proof of this right is often interpreted as a title deed. ${ }^{6}$

Although the main function is the land rights certificates as evidence, but the certificate is not the only evidence of land rights. The right to land someone they may be proved by other evidence. Certificates as evidence is very important for example in the case of transfer of rights and legal act of transfer of rights aims to transfer the land to another party (which qualify as rights holders), which include: selling - buying land, exchange, grant or grants wills and others - others.

But in reality in society often occur various problems associated with the certificate, one example of the problems associated with the certificate is the frequent occurrence of multiple certificates, as in the case set forth in Indramayu District Court Decision No. 44 / Pdt.G / 2017 / PN between Ety Kurniawati (Plaintiff) with Darkini Defendants, as well as, the Minister of Agrarian and Spatial cq Regency Head National Land Agency of West Java Province cq Head of the District Land Office Indramayu (Co-Defendant I), Home Minister cq Subdistrict Subdistrict Anjatan (Co-Defendant II), Home Minister cq Subdistrict District of Shukra (Co-Defendant III), Minister of Internal Affairs cq cq Subdistrict Subdistrict Village Head Shukra Shukra (Defendant IV), the District Subdistrict Home Minister cq cq Shukra Shukra Wetan village chief (Co-Defendant V) the disputed certificate No.337 / village Shukra (now Shukra Wetan) on behalf of Ety Kurniawati 1982 with a Certificate of Property Rights 61 in 1988 on behalf of Kayem and Darkini, the object of the dispute is the land area of $22750 \mathrm{m2}$.

A wide variety of problems that one of them is about double the certificate that until now there is no solution in BPN level or the State Administrative Court. Government in ensuring legal certainty in the field of control and ownership of land, making certainty the location and boundaries of each plot as a factor and a top priority that can not be ignored.

From past experience quite a lot of land disputes arising as a result of the location and boundaries of land areas are not true. Because of the problems of measurement and mapping as well as the provision of large-scale maps for the purposes of the implementation of land registration is a matter that should not be overlooked and is an important part that needs serious attention and careful, not only in the framework of data collection control over land but also in the presentation of data exploitation / land ownership and storage of such data.Background Based on the description above, the authors are interested in researching on "Settlement of disputes as Double Up Certificates in Indramayu Land Office".

This study sought to answer concerns regarding the settlement of disputes over double certificates in the National Land Agency Indramayu district, as well as the barriers and solutions to the dual certificate in Indramayu District National Land Agency

\section{Research methods}

The approach used in this paper is empirical sociological juridical with the help of

\footnotetext{
${ }^{5}$ Elza Syarief, 2012, Menuntaskan Sengketa Tanah, PT. Gramedia. Jakarta, p. 21

6 Mhd. Yamin Lubis and Abd. Hukum Pendaftaran Tanah, Mandar Maju, Jakarta, p.205
} 
Volume 6 Issue 4, December 2019

Nationally Accredited Journal,

Decree No. B/4130/E5/E5.2.1/2019

primary data or empirical data as the main data. Methods of collecting legal material in this research is with interview and review of literature. The data were analyzed qualitatively normative which analysis is used without the use of numbers and statistics and mathematical formulas presented in the description means. Where the results of the analysis will be presented descriptively.

\section{Results and Discussion}

\subsection{Settlement of Disputes Over Double Certificates in the National Land Agency Indramayu District}

Land issues now have penetrated the complex social issues and require a solution with a comprehensive approach. The development of the nature and substance of the case of land disputes is no longer just a question of land administration which can be resolved through administrative law, but the complexity of the land has penetrated to the realm of the political, social, cultural and related to nationalism and human rights. ${ }^{7}$ Not a few casualties for questioning or maintaining the land only a few square. From year to year, the number of cases in the area of land in Indonesia continues to increase. Within two years, the number of reported cases of National Lands Agency (BPN) of the Republic of Indonesia has increased five thousand cases. ${ }^{8}$

The lack of transparency in terms of control and ownership of land caused by the limited data and information control and ownership of land, as well as the lack of transparency in the information provided in the community is one of the causes of land dispute. This leads to the concentration of authorization and ownership of land in rural area and / or the number of parcels of land in urban areas, only a small minority of society. On the other hand land certification still seem inclined to demand access, which is far beyond the supply side, although projects such as land administration and adjucation project relatively successfully achieved its objectives. ${ }^{9}$ When examined, the land conflict that occurred during this spacious dimensions, both horizontal and vertical conflicts conflict. Vertical most dominant conflict is between the public and the government or state-owned and private-owned enterprises. For example, one of the most prominent case is the case of recognition of a plot or reclaiming. While the horizontal conflicts that occur most often double or ownership certificate issue multiple certificates on a plot. $^{10}$

Double the certificate on the ground is an event where a parcel of land has two land certificates, and certificates of land owned by different parties and these parties feel aggrieved with one another. This dual certificate dispute occurs usually due to an administrative error by the National Land Agency (BPN) to perform data collection or registration of land land on an object that resulted in the issuance of land titles which

\footnotetext{
7 Eko Yulian Isnur, SH, 2012, Tata Cara Mengurus Segala Macam Surat Rumah Dan Tanah, Pustaka Yustisia, Yogyakarta, p.47

${ }^{8}$ Ibid, p. 59

${ }^{9}$ Adrian Sutedi, 2012, Sertifikat Hak Atas Tanah, Second Print, Sinar Grafika, Jakarta, 2012, p. 186

10 Angga, Penyelesaian Terhadap Sertifikat Ganda Oleh Badan Pertanahan Nasional, Jurnal Lex et Societatis, Vol. I / No. 5 / September / 2013, p. 31
} 
overlap in part or the whole land owned by others. ${ }^{11}$

The conflict over control and ownership of land in the village on the District Wetan Shukra Sukro Indramayu district that certificate No. 337 / village Shukra (now Shukra Wetan) on behalf of Ety Kurniawati 1982 with a Certificate of Property Rights 61 in 1988 on behalf of Kayem and Darkini, the object of the dispute is the land area of 22 $750 \mathrm{~m} 2$. The claimant is Ety Kurniawati) and the Defendant is Darkini. In consideration of the Panel of Judges has argued:

- Purchase agreement between Wardam (Plaintiff's father) to Carlim (Father Darkini), Kayem and Darkini based Purchase Deed No. 337/172/1980 dated June 19, 1980 are valid.

- There has been a payment of disputed land prices by Carlim, Defendant's father, told Wardam.

- Recording into a book Letter C No. 5327 on behalf of Plaintiff on September 11, 1981 as the transition from C Letter No. 5174 on behalf Kayem and Darkini which the Letter C No. 5174 came from the Letter C No. 3174 on behalf of Wasni Karban is invalid.

From the above considerations, the Court found the legal owner of the disputed land is the Defendant and Purchase Deed No. 337/172/1980 dated June 19, 1980 is valid so Certificate Properties Number 61 Village Shukra Wetan on behalf Kayem and Darkini and Figure Situation (Measure letter) No. $783198822150 \mathrm{~m} 2$ area as a whole are made based on Purchase Deed No. 337/172/1980 was valid, the certificate on behalf of Properties 337 Ety Kurniawati 1982 declared null and void.

The land dispute settlement procedure double certificates, among others:

- Their complaints to the BPN Indramayu about the object of the disputed land. then to the section of the report the administration makes a recommendation letter addressed to sexy disputes, conflicts and land cases in order to continue handling the problem.

- The calling upon the parties to the dispute. Section to disputes, conflicts and cases of land to create a summons to the parties to the dispute to be holding Mediation. In case of a dispute over the Court has sought mediation with the path of peace among the parties to mediation as provided for in Minister Regulation No. 1 of 2016 on Procedures Mediation in the Court by appointing Agus Triyanto, $\mathrm{SH}, \mathrm{MH}$, Judge at the District Court Indramayu as a mediator, but by Mediators report dated December 14, 2017, peace efforts were not successful.

- Because mediation is not successful then the case was continued with the proceedings.

The process for resolving disputes Certificate Dual In District Court Indramayu according Writer aspects that influence the judge determines the course of action in the resolution of a dispute over double the certificate that is in terms of proof, because the facts and events as the principal case will be known judge from the evidence submitted by the parties dispute. If proof of plaintiff lawsuit will be granted, where a claim is granted sometimes granting wholly or reject others. So in the lawsuit denied the decision was determined obligations that must be performed by Plaintiffs Certificates of revocation of the land concerned.

Regarding consideration of the judge who is one of the most important aspects in

11 Utama Ansari, Penyelesaian Sengketa Sertifikat Ganda Hak Atas Tanah oleh Badan Pertanahan Nasional Tapanuli Utara, North Sumatra University Law Journal in 2019, p.3 
Volume 6 Issue 4, December 2019

Nationally Accredited Journal,

Decree No. B/4130/E5/E5.2.1/2019

determining the realization of the value of a judge's decision that contain justice and contain legal certainty, as it also should contain a benefit to the parties concerned so that consideration of the judge must be addressed carefully, and meticulously. Where intrinsically load consideration should judge on the following matters: ${ }^{12}$

- The subject and the things that are recognized or arguments not refuted.

- Their juridical analysis on all aspects concerning all facts / things that are proven in the trial.

- The considerations judicial magistrate with a starting point in the opinion of the doctrine, evidence and jurisprudence.

- The presence of all parts of the petition of Plaintiff should be considered or tried one after the other so that the judge can draw conclusions about whether or not proven and can be granted or whether the charges in the verdict.

Concerns about the legal decision that can be applied to resolve the dispute by a judge, basically shows that before dropping a judge's decision to do research in order to find the law. In addition, when one of the parties to the dispute has denied the authenticity of the documentary evidence submitted by the opposing party, the Judge may conduct an examination of the objection and then consider the final verdict on the value of evidence.

Because, in principle, the strength of documentary evidence lies in the original deed. Because in terms of the settlement in court, it will be seen the authenticity of each certificate, are actually published by the National Land Agency, Historical acquisition certificate which concerns not only the age, but also ways to obtain the certificate if it has been through the correct legal procedures ( ranging from the purchase until the issuance of the certificate), as well as the background of the issuance of the certificate. Thus the judge has tried as much as possible to be able to impose decisions that objective, fair and not influenced by any element except the attitude of objectivity and fairness it alone. However, sometimes the decision is not satisfactory either party or even both sides.

\subsection{Barriers and Solutions Upon Completion Certificate Associate at the National Land Agency Indramayu District}

Land Registry is a series of activities undertaken by the government continually and regularly, in the form of information or a specific data collection, processing, storage and presentation for the benefit of the people, in order to guarantee legal certainty in the field of land, including the issuance of the proof marks and maintenance. ${ }^{13}$

Registration of land has an output in the form of land titles. The term certificates of land is never mentioned in the Law on the Basic Regulation of Agrarian, but as found in Article 19 paragraph (2) c of the Law on Basic Regulation of Agrarian mentioned "letter of proof of the right". In the letter the everyday sense proof of this right is often

\footnotetext{
12 Interview with the Indramayu District Court Judge Elizabeth Inscription Asmarani, $\mathrm{SH}$, dated October 25, 2019

13 Boedi Harsono, 2007, Hukum Agraria Indonesia, Sejarah Pembentukan Undang-Undang Pokok Agraria, Isi dan Pelaksanaanya, Jilid I, Edisi Revisi, Cetakan Kesebelas, Djambatan, Jakarta, p.72
} 
interpreted as a land certificate. ${ }^{14}$

Certificate of Land Ownership (SHM) is a type of certificate with full rights of ownership of land or land by the certificate holder. SHM is a tool of the most powerful proof of ownership of land or land in question, because there is no interference or possible ownership by another party. ${ }^{15}$

Obstacles in resolving disputes in Indramayu double certificates are:

\subsubsection{Parties to the dispute does not come}

Mediation by the parties with the assistance of a mediator aiming to reach an agreement the two sides mutually beneficial (win-win) and satisfactory to the parties to the dispute as well as the nature of problem solving, rather than to seek a zero-sum (win or loss). The objectives will be achieved if both sides want a peaceful solution beneficial. But the fact of the parties to the dispute in the field did not come for various reasons, making it difficult to mediate between the two. Although mediators are ready but the parties to the dispute does not come, then the mediation process is inhibited. So that these problems do not finish protracted.

\subsubsection{Data on the land question posed is not clear}

Inequality data received by the Land Office Indramayu it confusing and difficult for a mediator in analyzing the problems. Inequality occurs when the parties report with different information so difficult to establish the mediation.

\subsubsection{Each party wants to win the case and the importance of their own interests.}

In the issue of land disputes each party has its own arguments and self-righteous. In the question of land as well as other civil disputes, generally there is an individual who feels disadvantaged or violated their rights by other individuals. This is impeding the mediation.

Solutions that can be done is the mediator to give some advice to the parties in order to be able to better cooperate in following the legal process, which is to better control the emotions, providing an explanation and description of the truth, and and provide evidence of concrete to resolve disputes so that can be done immediately and it takes a long time.

The legal consequences with their dual certificate that does not provide legal certainty, for the purpose of registering land is a person to obtain a certificate as proof of the perfect tool. But with the emergence of dual certificate then cause legal uncertainty in terms of enrollment land. Said not provide legal certainty because no two are on the legal status of the land. With the dual certificate can lead to distrust the Community to the legal certainty of land rights in this distrust of the certificate. As should the land certificates are proof of land ownership is strong, but how strong it can be said that if there were two certificates of land the same object,

\section{Closing}

\subsection{Conclusion}

\footnotetext{
${ }^{14}$ Mhd. Yamin Lubis and Abd. Rahim Lubis, 2008, Hukum Pendaftaran Tanah, Mandar Maju, Jakarta, p. 6

${ }^{15}$ Chandra S 2005, Sertifikat Kepemilikan Hak Atas Tanah : Persyaratan Permohonan di Kantor Pertanaan, Grasindo, Jakarta, p.25
} 
Volume 6 Issue 4, December 2019

Nationally Accredited Journal,

Decree No. B/4130/E5/E5.2.1/2019

Based on the description above, the conclusions of this research are:

- Settlement of disputes over double certificates in the National Land Agency Indramayu district among other things: a). Their complaints to the BPN Indramayu about the object of the disputed land. Then on the section of the report the administration makes a recommendation letter addressed to sexy disputes, conflicts and land cases in order to continue handling the problem. b). The calling of the parties to a dispute to mediation. c). If mediation is not successful then the case was continued with the proceedings. The dispute settlement process Certificate Dual In Indramayu District Court, aspects that influence the judge determines the choice of action in the resolution of a dispute ie double certificate in terms of proof,

- Barriers and Solutions Dual Certificate Upon completion, namely a). Parties to the dispute does not come for various reasons, making it difficult to mediate between the two. Although mediators are ready but the parties to the dispute does not come, then the mediation process is inhibited. So that these problems do not finish protracted. b). Data on the land question posed is not clear. Inequality occurs when the parties report with different information so difficult to establish the mediation. c). Each party wants to win the case and the importance of their own interests.

Solutions that can be done is the mediator to give some advice to the parties in order to be able to better cooperate in following the legal process, which is to better control the emotions, providing an explanation and description of the truth, and and provide evidence of concrete to resolve disputes so that can be done immediately and it takes a long time.

\subsection{Suggestion}

- Should be to prevent the Certificate Dual Landrights later BPN more careful and pay attention about the factors that cause the appearance of double certification, where these factors must be improved, for example in land registration, before being processed or measured, it should be conducted checks on the map registration soil to determine whether the piece of land that are already registered (certified) or not at the National land Agency.

- The public should be more careful and meticulous when buying land. After buying and selling of land, cultivated should doing behind the name with register to the local land office. Negligence care of behind the name is going to increase the chances of claiming a letter or certificate of land later by others.

\section{References}

[1] Arie S. Hutagalung, 2005, Perlindungan Pemilikan Tanah dari Sengketa Menurut Hukum Tanah Nasional, Tebaran Seputar Masalah Hukum Tanah, Lembaga Pemberdayaan Hukum Indonesia

[2] Elza Syarief, 2012, Menuntaskan Sengketa Tanah, PT. Gramedia. Jakarta

[3] Mhd. Yamin Lubis dan Abd. Rahim Lubis, 2008, Hukum Pendaftaran Tanah, Mandar Maju, Jakarta

[4] Eko Yulian Isnur, 2012, Tata Cara Mengurus Segala Macam Surat Rumah Dan Tanah, Pustaka Yustisia, Yogyakarta

[5] Adrian Sutedi, 2012, Sertifikat Hak Atas Tanah, Ctk.Kedua, Sinar Grafika, Jakarta, 
[6] Angga, Penyelesaian Terhadap Sertifikat Ganda Oleh Badan Pertanahan Nasional, Jurnal Lex et Societatis, Vol. I/No. 5/September/2013

[7] Utama Anshari, Penyelesaian Sengketa Sertifikat Ganda Hak Atas Tanah oleh Badan Pertanahan Nasional Tapanuli Utara, Jurnal Hukum Universitas Sumatera Utara tahun 2019

[8] Boedi Harsono, 2007, Hukum Agraria Indonesia, Sejarah Pembentukan UndangUndang Pokok Agraria, Isi dan Pelaksanaanya, Jilid I, Edisi Revisi, Cetakan Kesebelas, Djambatan, Jakarta

[9] Mhd. Yamin Lubis dan Abd. Rahim Lubis, 2008, Hukum Pendaftaran Tanah, Mandar Maju, Jakarta

[10] Chandra S, 2005, Sertifikat Kepemilikan Hak Atas Tanah: Persyaratan Permohonan di Kantor Pertanaan, Grasindo, Jakarta 